\title{
NEW TECHNOLOGIES AND LANGUAGE SHIFTING IN VANUATU
}

\author{
Leslie Vandeputte-Tavo
}

\begin{abstract}
During the last few years, mobile phones and social networks have deeply changed relationships and, insidiously, the use and representations of languages in Vanuatu. In spite of being very recent, it seems that new ways of communication imply changes regarding the various ways of using and adapting languages, amongst which are code-switching and language-shifting. Bislama, the national local lingua franca, is becoming more and more used in phone conversations. Internet and especially social networks (such as Facebook) are revealing new language strategies in social intercourses.

This article examines interactions of languages that are mediated through social networks and mobile phone exchanges. More specifically, this paper discusses different language ideologies that are manifest in and deployed over forms of telecommunication.
\end{abstract}

Keywords: Bislama; Pidgin; Ethnolinguistics; Mass media; Telecommunication; Linguistic ideology; Port-Vila; Vanuatu.

\section{Introduction}

As many other small Pacific countries, Vanuatu has recently been the theater of an important telecommunication (mobiles, Internet) "revolution" which is currently still in progress. During the last few years, mobile phones and social networks (an Internetbased media program to make connections), have deeply changed social relationships and, insidiously, the use and representations of languages in Vanuatu. Digicel, the most important international telecommunication operator, arrived in Vanuatu in June 2008, giving Melanesians an easy access to mobile phones while experiencing its facilities and pernicious effects at the same time. The service is now available to over 80 percent of the population and "more and more ni-Vanuatu move to embrace the Digicel age 1 ." According to the 2009 National Census, 76\% of households own or have access to a mobile phone. If Internet connexions are far from being as common and popular as mobile phones can be, Internet is nevertheless slowly becoming an extra urban way to 'get in touch' (Internet connexions are currently available to $8 \%$ of the population ${ }^{2}$ ).

In spite of being very recent, it seems that these new ways of communication

\footnotetext{
${ }^{1}$ Vanuatu Daily Post, 17 septembre 2009.

${ }^{2}$ UN International Telecommunications Union statistics for 2010.
} 
have already implied changes regarding the various ways of using and adapting languages, including code-switching, code-mixing and language-shifting. On the one hand, Bislama, the national local lingua franca, is more and more frequently used in phone conversations, while on the other hand; vernacular languages are slowly being adapted to short text messages (SMS). Internet and especially social networks such as Facebook or MySpace are revealing new language strategies in social intercourses. As an incarnation of power (O'Barr 1982), the study of language, here in the use of new technologies, turns out to be a particularly "fertile" tool. As such, it provides us with keys for a better understanding of social relationships in urban Vanuatu, (like the ones between men and women in particular).

In this paper, I wish to examine every-day language interactions that are mediated through social networks and mobile phone exchanges. More specifically, I will look at the different language ideologies that can be observed and deployed over telecommunication. Using specific ethnographic examples such as short text messages, groups of interests on social networks and mobile conversations, I will argue that in Vanuatu, both mobile phones and the Internet are showing some type of language shifting ideology, especially through the young generation.

\section{The democratization of telecommunications in Vanuatu}

\subsection{Technology, modernity and linguistic ideology}

To Ni-Vanuatu people, the introduction of technology in their country (radio, television, mobile phones and computers) evokes "modernity", which is understood as an idea of progress, sophistication, consumption, innovation and Westernization. This modernity is experienced through the acquisition of consuming goods, a certain type of knowledge (non-traditional), technologies and as a way of accessing a higher social status and a better life. With respect to Zambia in (Southern) Africa, Debra Spitulnik (1998: 63) suggested that the history of electronic media reflects the complex meanings of modernity from the end of the colonial period until the country's independence (in 1964). According to Spitulnik, the incarnation and the diffusion of the idea of "modernity" through the radio causes language changes and adaptations.

We believe that in Vanuatu telecommunication plays more or less the same role that Spitulnik described with respect to the radio (and more broadly with Mass Media) in Zambia: Telecommunication and the idea of modernity attached to this reality are responsible for language shifts. Mobile phones and more exclusively the Internet are taken as new tools which incarnate power and modernity in and for Vanuatu society.

Consequently, we assume that language and linguistic repertoires used in these specific telecommunication contexts benefit from a valorised opinion as well, appearing to be a more "legitimate" language in the "linguistic market" (Bourdieu 1982). If we agree with Bourdieu's assumption which stands that any linguistic exchange is necessarily both a social and an ideological positioning in the linguistic hierarchy of the established linguistic market (Bourdieu \& Boltanski 1975; Bourdieu 1982), the language chosen by the speaker, therefore, appears to be relevant for analyzing shifts, since it reflects ideologies that are associated to each language (and linguistic repertoire) that is used.

Mobile phones as well as the Internet are relevant vectors of oral and written 
expressions through which people reveal their representations and beliefs about languages as they are used in social interaction (this is what linguistic-anthropologists have called "linguistic ideology"). Michael Silverstein (1979: 193) defined linguistic ideologies as "sets of beliefs about language, articulated by users as a rationalization or justification of perceived language structure and use". This concept of language ideology, which we have used in our fieldwork research, has been very prolific in the past decades (see Woolard 1998) because language-ideological approaches emphasize: "Political economic forces [...] diversity and contestation, the influence of speakers' life [...]" (Kroskrity 2005: 501) and provide useful tools (for researchers). According to Paul Kroskrity language ideologies contain five levels of organization: The first level has to do with individual interests, the second one with the multiplicity of ideologies, and the third level deals with awareness of speakers whilst the forth one is about mediating functions of ideologies. Finally, the fifth role of a language ideology develops identity construction. Those levels are important in order to understand the complexity and the way in which individual speakers, groups and governments use language to create and negotiate their own socio-cultural worlds. We will focus here on language and language ideologies shifts in the context of telecommunication uses.

\subsection{Mobile-phones in Vanuatu}

The recent implantation of a new telecommunication company (Digicel) which highly promotes accessibility to mobile phones, has played a key role in the development of telecommunications in Vanuatu. The extended Digicel network coverage of the entire archipelago has helped reducing space and distance, as well as democratising the use of mobile phones. This phenomenon is recent and is subsequent to the opening of a competitive market, (until 2007 Telecom Vanuatu Limited (TVL) held the monopoly in the sector). In 1980 after the independence of Vanuatu, the company VANITEL and the Posts and Telecommunications Department (TPD) both used to ensure all international communications. In 1989, TPD was replaced by the National Telecommunications of Vanuatu Limited (NTV), and it became Telecom Vanuatu Limited (TVL) in 1992 (Siméoni 2009: 342). In 2002, the replacement of the analogue cellular network GSM by a digital network has gradually enabled the mobile phone market to grow consistently. However, although it was technically possible to use a mobile phone, cellular access did not really develop until 2008, when Digicel bumped the telecommunications market in Vanuatu, which amongst other things, resulted in lower prices for mobile phones and phone calls.

Today, a large part of the population owns a cell phone ${ }^{3}$. Due to the expansion of network coverage in very remote areas and to the relatively low cost of a mobile device (between 1000 and 3000 vatu for the first models, i.e., approximately between 9.- $€$ and

\footnotetext{
${ }^{3}$ According to a recent study realized by the Pacific Institute Public Policy (PIPP) and published in 2009, mobile phones' development has already had several effects in Vanuatu:

1. The overwhelming majority of households in Vanuatu has access to a mobile phone. Four out of five respondents reported personally owning a mobile phone and an increasing number of households have access to three or more mobile phones

2. Mobile phone usage is higher in urban areas than in rural locations, reflecting issues of more limited coverage, cost (whether actual or perceived) and reliability of service [...] » (Sijapati-Basnett 2012: 1).
} 
26.- $€$ ), the gap between access to telephones in rural and urban areas is gradually decreasing. Users, rural and urban alike, both send and receive text messages, send many "please call me" (a free service offered by Digicel) messages, listen to music, take and watch photos or videos, play games, or use mobiles as a torch at night. Mobile phones have turned out to be the way of communication for which the ni-Vanuatu spend most money ${ }^{4}$.

Interlocutors (both rural and urban) have experienced the changes following the arrival of mobile phones such as: Reducing distances, having regular contact with families and friends, limiting isolation, giving a sense of security (by getting information on natural disasters for example or being able to call someone in case of an accident, etc.), maintaining relationships or meeting someone . $^{5}$

Mobile phones are visibly everywhere, in the supermarket, at the post-office, in kava-bars etc.; it is currently impossible not to find people playing with their cell phones, ringing someone or texting a friend. It has definitely changed ni-Vanuatu peoples daily lives as well as involving various linguistic adaptations.

\subsection{The Internet in Vanuatu}

The Internet hasn't had the same success as mobile phones yet, mainly because its access is a lot more limited. Since 2006, Telecom Vanuatu Limited ${ }^{6}$ (TVL) which has the monopoly of the telecommunication network in the country has been trying to improve Internet connections (256 kbits per seconds) thanks to communication technology ADSL (Asymmetric Digital Subscriber Line) ${ }^{7}$. Given the lack of structures, access to the Internet still remains located to two urban centres, although there is a wish to see the network grow and extend to all - or most of - the islands. ${ }^{8}$.

According to the last national census in 2009 , only $6.65 \%$ of the population aged over fifteen years old had a regular Internet connection; however this figure varies

\footnotetext{
${ }^{4}$ According to the PIPP report $62 \%$ of the urban population regularly spend more than 1000 vatu to credit their phones (2009: 33).

${ }^{5}$ Meeting by phone can be through services discussions (chat) that connect different users, but also through a practice widespread in Vanuatu which is to compose a random number (which hopefully falls on the opposite sex) and maintain conversation with this person. Several persons tell the story of couples who have formed though mobile phones, one of my interlocutor: « sapos $i$ no gat Digicel ol man bae oli no save faenem woman! » (« If Digicel doesn't exist, men won't be able to find women! »).
}

${ }^{6}$ Telecom Vanuatu Limited is owned equally between France Telecom and Cable and Wireless (a UK company telecommunications). TVL until 2007 had an exclusive license to operate telecommunications in the archipelago. However, the government decided to put an end to this monopoly, and withdrew its share of TVL (which it shared with two other shareholders (Siméoni 2009: 342)).

${ }^{7}$ A project to install fiber optic links to the archipelago of New Caledonia or Fiji should be started in 2013, this new facility would allow a much faster connection to the Internet.

${ }^{8}$ Gradually, some rural towns have begun to offer Internet connections. TVL displays a willingness to generalize the use of the Internet to rural communities. In Lenakel (Tanna), Lakatoro (Malekula) or Lamap (Malekula) it is now possible to connect to the Internet from a post office or from the hospital. Although these services are particularly expensive, they are indicative of an opening of "islands" of new technologies, and herald a democratization of Internet usage. 
throughout the provinces ${ }^{9}$. Although Internet seems still to be in its infancy, a report based on a survey conducted in Vanuatu in 2008 by the Pacific Institute of Public Policy (PIPP), highlighted the ni-Vanuatu's interest for this new technology:

«Use of the Internet, whilst growing is still very much in its infancy but people in both urban and rural areas are keen to know more about this technology and are already anticipating the advantages it will bring them both socially and economically.» (Sijapati-Basnett 2009: 1)

Let's add that Internet users are generally educated urban ni-Vanuatu (mostly men), however, with the ability to access the Internet in public places like Internet cafes its use gradually tends to include a wider audience (usually young people between the age of 16 and 35 years). The Yut Senta (Youth Centre) provides computer training courses where one can acquire basic skills on how to surf on the net. Moreover, there are also people who can access the Internet at work (teachers, public servants or government officials etc.).

In spite of a relatively limited access to the Internet, ni-Vanuatu people have been seduced by the possibilities it offers, which include in particular networking websites such as Facebook. In a recent article Anna Naupa noted that $38 \%$ of the people who are regular Internet users (approximately $7 \%$ of the population) are listed on Facebook; this number increases constantly.

The Internet has a great reputation among the ni-Vanuatu population, although a great majority of the people usually do not know what this telecommunication tool actually is. Nevertheless, it is considered to be a powerful and mysterious way to communicate with peoples and sites outside of Vanuatu.

The novelty of the Internet which opens up the world for its users and the "power" brought by this new technology is one of the reasons for analyzing the linguistic practices observed on social networks, during mobile phone conversations and in text exchanges. Leading questions are: What languages and which linguistic repertoires are used in those discussions? What do we learn about the uses and the representations of languages developed in these contexts?

\section{Language shifting and telecommunication}

\subsection{The development and appropriation of Bislama}

Vanuatu is a well-known place for its extreme language diversity; according to Darrell Tryon 106 languages are spoken through the archipelago (see also Crowley 2000); English and French - both ex-colonial languages - are still the languages of education, Bislama is the lingua franca used between ni-Vanuatu. During the colonial period, English and French languages were symbolically positioned on the top of the linguistic "pyramid" (as languages of the former political power and languages of instruction).

${ }^{9}$ In Torba Province for example (in the far north of the archipelago in a region composed of small isolated islands) only $0.66 \%$ of the people have had a recent Internet connection (this percentage is probably due to the fact that people from this province are living in an urban area). In the Shefa Province, however, where the capital is located, $13.57 \%$ of the people had recently accessed the Internet. 
Nowadays those two languages still symbolically occupy a high position in the country as they are still the languages of education. Vernacular languages, as vectors of history and traditions on the other hand, have a cultural and symbolic role to play, while Bislama has trouble finding its place. However, the new means of telecommunication have highlighted and valorised the use of Bislama.

Bislama clearly dominates the majority of telecommunication interactions between ni-Vanuatu people. Being the lingua franca of Vanuatu, Bislama is used amongst ni-Vanuatu people who do not speak the same vernacular language (this is the most common situation in urban areas where mobile phones dominate). Given this situation, the increased use of mobile phones goes hand in hand with an increase of the use of the national lingua franca.

In the bigger towns like Port-Vila and Luganville where speakers of many different indigenous languages of Vanuatu live Bislama is slowly becoming a creole: Terry Crowley (2004: 7) estimated that about 10\% of Vanuatu's population speaks a Bislama as their first language. Words, idiomatic expressions, and swearwords in Bislama are progressively penetrating into vernacular languages in specific contexts and forms of mobile phone communication are (at least in part) responsible for this (see Lindstrom's (2007) studies on the influence of Bislama in the Kwamera language of Tanna).

In addition, Bislama starts to benefit from a prestigious and positive image which is linked to the participation in and the identification with the national community. The use of Bislama, particularly in urban settings, marks a person's engagement with the nation, the modern institutions and the urban lifestyles (characterized by media, popular music, technology, every-day consumption of kava in Port-Vila's kava-bars, etc.). Don Kulick (1992: 20) has shown that in small communities in Papua New Guinea Tok Pisin (PNG's pidgin) is locally associated with concepts such as "Christianity", "modernity", or "education". Just like Tok Pisin in PNG, Bislama in Vanuatu is partly associated with modernity. It is the use of Bislama in forms of mobile phones' communication which strongly contributes to this language shift ideology.

Bislama unfolds along a continuum ranging from a basilectal linguistic variety (close to the substrate language) to an acrolectal form of pidgin (close to the superstrate language). According to my fieldwork observations, the Bislama spoken in urban areas can be distinguished from other varieties by two features: First, it is an acrolectal form of pidgin which borrows much from English (sometimes one also observes codeswitching and/or code-mixing) and secondly, Bislama is an urban register which uses many neologistic expressions like for example swearing references which are specific to the urban environment. Progressively, Bislama is becoming more and more valorised on the "linguistic market" of the country. And it is telecommunication (both via cell phones and the Internet) which contributes to the spread of Bislama.

As to growing use of text messages - text, mesej, text-mesej or sms (the abbreviation for "short message service"), Bislama is the language of choice for the ni-Vanuatu. This is most probably the consequence of the very limited use of vernacular languages in writing; moreover, in the beginning of the text message development only young urban people who spoke Bislama used this form of communication. The peculiarity of text messages is the fact that a specific language (SMS language) is used which is characterised by the use of analogies, reductions and shortenings, paralinguistic and prosodic features, capitalization, etc. These features are not unique to Bislama; they also 
exist in most -if not all- languages with textual exchanges. Instant messages emphasize the use of pidgin in a new form:

(1) Ba mi go luk m lo taon, z?

Bae mi go luk hem long taon, stret?

I am going to see him in town, is it ok?

(2) U2fala nmo i talm

Yutufala nomo i talem

You tell me

(3) $1 \mathrm{~m}$ i no gud?

Wanem i no gud?

What's wrong?

Here, the two features of Bislama described previously are both conveyed through sms language. For example the word stret (literally straight which means in Bislama "it's fine", "it's ok") translates in the sms language by the letter $z$. This "z" is now a very common and "fashion" word (or rather: Letter) in urban Bislama. The adaptation of Bislama to sms language reveals that Bislama is a means for the urban youth to identify themselves. And this language ideology contributes to promoting pidgin emancipation and the national legitimacy of Bislama.

\subsection{The legitimacy of the pidgin}

Historically restricted to speaking, Bislama is slowly becoming a written language. Up until recently, writing was reserved to English and French, the "old" international and legitimate languages of instruction; nowadays, Bislama is no longer confined to verbal domains only. Mobile phones and the Internet have driven and promoted this change (hand in hand with advertisements, newspaper articles or government notices). As Jack Goody (2007) has shown, the power of writing is huge and mighty, and it severely influences language ideologies and representations.

English is more often used by ni-Vanuatu Facebook users than the French. However the minority of French speakers have a Facebook group entitled "Vanuatu Francophone" which accounts for nearly 420 ni-Vanuatu members all based in Vanuatu, New Caledonia or in France. Vernacular languages are sometimes used by Internet users who are native speakers, like for example by members of the same family (wan tok), when they comment on pictures, community news, etc.

However, ni-Vanuatu people generally use Bislama on social networks when they are: Posting messages on their Facebook "friends' wall" (the profile page of a person); commenting photos, making jokes, swearing to friends in a "joking" way or sharing experiences or references in a similar socio-cultural context.

Different forms of Bislama may be encountered on Internet social networks such as Facebook which are similar to verbal forms of Bislama described earlier: An acrolectal form of Bislama, a code-mixing with English (or sometimes French as well) and a codeswitching (mainly with English) as in the following examples: 
(4) S. N. T. mi respectem opinion blo yu mo due respect lo Mrs L. Wan problem nomo wetem leader blo yumi ia se fulap taem emi misjudgem, misinterpretem, misguidem mo confusum tinktink blo em lo ol important issues. Mi listen plante...

S.N.T. I respect your opinion and due respect to Mrs L. But the problem with our leaders is that very often there is misjudgment, misinterpretation, and confusion of thoughts on important issues. I am aware.

(5) Olgeta next meeting wetem Minista hemi wetaem follem issue blong vnpf ?.. plis need details..ta.

Notice to everyone, what date is scheduled for the next meeting with the Minister regarding the issue of VNPF? I need more details please... Thank you.

(6) Ino nidim enimore miting from hemi no gud issue wetem VNPF. Weit lo audit ${ }_{10}$ ripot nomo afta gat miting. Board blo VNPF hemi blong westem taem nomo...!!

It is worth making meetings, this is not the real problem VNPF. We have to wait for the audit report and then we can meet together. VNPF's Board is good-fornothing!

Written Bislama as it appears on social networks is characterized by an absence of spelling rules and by abbreviations; for example the possessive marker blong occurs in a shortened form as blo, and some verbs like the verb givim are abbreviated and are realized as gim. On the other hand, people use analogy sounds to reduce the time of writing, as in the example hem writing with the simple letter $m$ (this is one of the sms characteristic features mentioned earlier). Example illustrates these forms of written Bislama used in social networks:

(7) Olgeta lo matevulu $e$ bin late lelebet blo gim mani....

Matevulu people had delayed in payment ...

so lo taem we uncle ya shud pem ol work boy's blem...m short smol......

so when the uncle should have paid its employees ... it was a little courtyard ...

so $m$ stp ringim olgeta lo matevulu blo talem about mani we oli owem $m$....

so he tried to call people to tell them about Matevulu money that they owed him...

...be $e$ gat wan olfala man lo west ambae....nem blem ba me no talem.... ...but there was an old man from Ambae island ... I would not tell his name ....

The whole time uncle ya stp ring...m stp sta quiet stp listem lem stap kol....

The whole time this uncle tried to call ... he stayed quiet to listen to what the uncle said ...

\footnotetext{
${ }^{10}$ I note in italics which is part of code-switching. Examples extracted from the discussion group on Facebook called Yumi Toktok Stret (Straight Talk) published in August 2012.
} 
problem se olfala ya sorai fas smol.....about the sixth time we uncle ya ring... but the old man was deaf ... and after the sixth time that uncle called ...

olfala man ya curious now....so $m$ askm uncle ya se....

the old man was curious ... so he asked

"hey u stap talem wanem ya lo phone......andapan?"

"hey what are you talking about on the phone ... underwear? "

uncle ya taem $m$ harem from smol kross nomo and harem nomo wantem toktok kerap talem....

When the uncle heard that he was a little angry he just wanted to stand up and say

"yes".... olfala man nomo harem number 2 time.......m kerap ansa se....

"yes" ... the old man responded a second time and got up saying,

"eh brata.....u no worry.... me samting ya me leko long time vnis.....

"Hey my brother ... do not worry I dropped ... this stuff long time ago"11.

In this extract the expression blong hem (to him) and long hem (for him) were both contracted on blem and lem. Moreover, the predicative marker $i$ is written with an English phonology with the letter $e$ which is showing code-mixing with English.

Using Bislama on the net which is understood as a symbol and means of openness to the world, implies for the users of this national lingua franca that they identify themselves as being ni-Vanuatu people.

A form of Bislama which is considered to be more "developed" and less "common" will be valued and therefore favoured by writers like an acrolectal form of Bislama. In the absence of Bislama literature (in the narrow sense of the term for the domain of Letters) which would have imposed a standard to be achieved, it is the formal writing of broadcast productions that define the style and the literary form of the pidgin. Press, politicians and public officials, adopting a predominantly acrolectal Bislama, develop, legitimize and impose this form of the national lingua franca. The appropriation of Bislama on the net is legitimating the pidgin as well as it is developing and enriching the language. Bislama which was for a long time the "plantation language" is getting more and more valorised and legitimate through its written forms used in forms of Internet communication.

\section{Conclusion.}

Although the Bislama language became the national language of the Republic of Vanuatu already in 1980, it remained - up until very recently - a "discount" language, a depreciated language whose use was not much rewarding neither orally nor in writing. The arrival of Telecommunications has recently caused a progressive change in the

11. Italics mark code-switching. The examples are extracted from the discussion group on Facebook called Yumi Laf Smol (a bit of laugh), published in August 2012. 
speakers' attitude towards Bislama. Its use in a field valued and related to modernity has led to a change of attitude, gradually creating and increasing the value and legitimacy of this lingua franca. Instant messages, telephone conversations as well as written exchanges on social networks in Bislama reveal that the ni-Vanuatu identify themselves with and through this language. Moreover, the development of a written form of the pidgin on the Internet provides the former pidgin language with a new authority. In this socio-linguistic landscape, Bislama is gaining influence at the expense of English and French, although these "colonial" languages remain authorized as the languages of education in the country as well as prestigious international languages.

\section{References}

Bourdieu, P., and L. Boltanski (1975) Le fétichisme de la langue. Actes de la recherche en sciences sociales 1.4: 2-32.

Bourdieu, P. (1982) Ce que parler veut dire : l'Économie des échanges linguistiques. Paris: Fayard.

Crowley, T. (2000) The language situation in Vanuatu. Current issues in Language Planning 1.1: 47-132.

Crowley, T. (2004) Bislama reference grammar. Honolulu: University of Hawai'i Press.

Goody, J. (2007) Pouvoirs et savoirs de l'écrit. Paris: La Dispute.

Kroskrity, P. (2005) Language ideologies. In A. Duranti (ed.), A companion to Linguistic Anthropology. Malden, Mass.: Blackwell Publishing, pp. 496-517.

Kulick, D. (1992) Language Shift and Cultural Reproduction: Socialization, Self and Syncretism in a Papua New Guinean Village. Cambridge: Cambridge University Press.

Lindstorm, L. (2007) Bislama into Kwamera : Code-mixing and language change on Tanna (Vanuatu). Language Documentation and Conservation 1.2: 216-239.

O’Barr, W. (1982) Linguistic evidence: Language, power, and strategy in the courtroom. New-York: Academic Press.

Sijapati-Basnett, B. (2009) Social and economic impact of introducing telecommunications throughout Vanuatu : Research findings. Port-Vila : Pacific Institute of Public Policy.

Silverstein, M. (1979) Language structure and linguistic ideology. In R. Clyne, W. Hanks, and C. Hofbauer (eds.), The Elements : A parasession on Linguistic Units and Levels. Chicago: Chicago Linguistic Society, pp. 193-247.

Siméoni, P. (ed.) (2009) Atlas du Vanouatou (Vanuatu). Port-Vila : Editions Géo-Consulte.

Spitulnik, D. (1998) Mediated modernities: Encounters with the electronic in Zambia. Visual Anthropology Review 14.2: 63-84.

Woolard, K. (1998) Introduction: Language ideology as a field of inquiry. In B. Schieffelin, K. Woolard, P. Kroskrity (eds.), Language Ideologies: Practice and Theory. Oxford: Oxford University Press, pp. 347. 
LESLIE VANDEPUTTE-TAVO is a Ph.D. Candidate in Social Anthropology at the Centre of Research and Documentation for Oceanists (CREDO) at Marseille (France). Her research interests are focusing on language ideologies, creole and pidgin languages, language and identity and language contact. She has conducted her Ph.D.'s fieldwork in Vanuatu (South Pacific) on the national language of the country: The pidgin bislama.

Address : Centre de Recherche et de Documentation sur l'Océanie - Aix Marseille Université, CNRS, EHESS, CREDO UMR 7308, Campus St Charles, 3 place Victor Hugo, 13003 Marseille, France. E-mail: leslievdp@gmail.com 